\title{
Quantitative genetic analysis for meat tenderness trait in Polled Nellore cattle ${ }^{1}$
}

\author{
Análise genética quantitativa da característica maciez da carne em bovinos Nelore \\ Mocho
}

\author{
Letícia Mendes de Castro ${ }^{2 *}$, Cláudio Ulhôa Magnabosco ${ }^{3}$, Roberto Daniel Sainz ${ }^{4}$, Carina Ubirajara de Faria ${ }^{5}$ e \\ Fernando Brito Lopes ${ }^{6}$
}

\begin{abstract}
The aim of the present study was to analyze the interrelationships among the variables and also estimate the genetic correlations between tenderness (WBSF), growth (ILW, FLW and ADG) and carcass (BF, RF and LMA) features. Other purpose was to identify individuals who were more likely to be carriers of favorable genes for tenderness. Growth, carcass and tenderness data from 415 Polled Nellore animals was analyzed. Factor analysis and canonical correlations were used to analyze the phenotypic relationships. The covariance components and genetic parameters were estimated using Gibbs Sampling method. Lack of phenotypical correlations between the WBSF and the other traits were observed. The genetic correlations between WBSF and the other evaluated traits were of a low magnitude, with values of $-0.15 ;-0.18 ;-0.13 ; 0.10 ;-0.12$ and 0.18 , between WBSF and ILW, FLW, ADG, BF, RF and LMA, respectively. The results support the conclusion that tenderness selection will not affect the selection of other economic traits and vice-versa, but for a better knowledge of the genetic relationships between meat tenderness and other traits for Polled Nellore more studies are required. The heritability estimated for WBSF was of a low magnitude $(0.11 \pm 0.022)$. Based on the principle of probability of identical genes by ancestry individuals who were more likely to be carriers of favorable genes for tenderness were identified. Further work will include creation of a segregating population that will serve as experimental material for future gene prospecting and identification research.
\end{abstract}

Key works: Carcass. Shear force. Pedigree.

RESUMO - Objetivou-se analisar os inter-relacionamentos entre as variáveis, além de estimar as correlações genéticas entre os grupos de características de maciez (FC), crescimento (PI, PF e GPD) e carcaça (EG, P8 e AOL). Foi proposto também, identificar indivíduos que apresentem alta probabilidade de serem portadores de genes favoráveis à maciez. Analisouse dados de 415 animais Nelore Mocho, filhos de touros representativos das principais linhagens Nelore, avaliados para características de crescimento, carcaça e maciez. Para análises de relacionamentos fenotípicos foram utilizadas análises de fatores e correlações canônicas. Os componentes de variância necessários à obtenção dos parâmetros genéticos foram estimados pelo método da Amostragem de Gibbs. Observou-se ausência de correlações fenotípicas entre FC e as outras características produtivas. As correlações genéticas entre FC e PI, PF, GPD, EG, P8 e AOL foram de baixa magnitude (-0,15; $-0,18 ;-0,13 ; 0,10 ;-0,12$ e 0,18$)$. A seleção para a maciez não influenciará na seleção de outras características de interesse econômico e vice-versa, porém serão necessários mais estudos para melhor conhecimento sobre as relações genéticas da maciez e outras características produtivas em bovinos Nelore Mocho. A estimativa de herdabilidade para a característica FC foi de baixa magnitude $(0,11 \pm 0,022)$. Baseando-se no princípio da probabilidade de genes idênticos por descendência, identificou-se indivíduos com alta probabilidade de possuírem genes favoráveis à maciez. Posterior trabalho irá incluir a criação de uma população segregante a partir desses animais identificados, que irá servir como população experimental para posterior pesquisa de prospecção e identificação de genes para maciez da carne em bovinos Nelore Mocho.

Palavras-chave: Carcaça. Força de cisalhamento. Pedigree.

\footnotetext{
* Autor para correspondência

Recebido para publicação em 28/11/2012; aprovado em 28/12/2013

Parte da Dissertação de Mestrado do primeiro autor; Pesquisa Financiada pela Embrapa/CNPq

${ }^{2}$ Programa de Pós-Graduação em Ciência Animal, Universidade Federal de Goiás, Bolsista Capes, Goiânia-GO, Brasil, leticia.castro@embrapa.br

${ }^{3}$ Embrapa Cerrados/CNPq, Brasília-DF, Brasil, claudio.magnabosco@embrapa.br

${ }^{4}$ Embrapa, Brasília-DF, Brasil, Professor da University of California, Davis-CA, EUA, roberto.sainz@embrapa.br

${ }^{5}$ Universidade Federal de Uberlândia, Uberlândia- MG, Brasil, carinauf@ famev.ufu.br

${ }^{6}$ Embrapa Cerrados, Bolsista Pós-doutorado Embrapa/Capes, Brasília-DF, Brasil, britolopes@ @npaf.embrapa.br
} 


\section{INTRODUCTION}

In Brazil, Zebu animals comprise around $80 \%$ of the national cattle herd, showing differences in growth and production potential between the different country regions and also between different management systems (FERRAZ; ELER, 2010). Several researchers have studied carcass, food intake and growth traits, such as weight at different ages, growth curves and features related to growth rate of Nellore cattle (BOUQUET et al., 2010; HERD; ARCHER; ARTHUR, 2004; HOQUE et al., 2009; LANCASTER et al., 2009; LOPES et al., 2011; LOPES et al., 2012; ROBINSON; ODDY, 2004; SOUZA et al., 2008; SANTOS et al., 2012). However, research to evaluate meat quality, especially tenderness and its relationships with growth and carcass quality traits of Zebu cattle in Brazil, are incipient.

In 2012, Brazil produced about 9.6 million tons of beef and, of these, approximately 1.8 million tons were destined for export (USDA, 2013), making Brazil the largest beef exporter in the world by volume. However, Brazil lags behind other global beef exporters in export value, losing to countries such as the U.S. and Australia (IBGE, 2011), because most of the beef exported by Brazil is considered of medium and low quality by international buyers.

Among the features that depreciate the quality of Brazilian exported beef is the low tenderness, mainly because most of that meat comes from animals with Zebu genetic background, known to be less tender than beef from Bos taurus beef breeds. However, research developed with Nellore cattle (SAINZ et al., 2005) has demonstrated the existence of genetic variability for beef tenderness, indicating that this trait can be improved through genetic selection. Some researchers suggest that differences for meat tenderness within same breed sires are greater than the mean differences for meat tenderness between sires from different breeds (BIANCHINI et al., 2007; SAINZ et al., 2005), indicating that the selection of the right sire can make all the difference.

Despite the fact that genetic improvement of beef tenderness in Zebu populations are of major importance, very few structured herds include this trait in their breeding programs, because Brazilian packers do not pay for meat quality as in other countries, rather they pay only for quantity. However, there are studies showing that consumers would be willing to pay more for meat quality, especially regarding meat tenderness (BOLEMAN et al., 1997).

In this context, we aimed to estimate the (co) variance components and genetic parameters for meat tenderness, growth and carcass traits, as well as adopt strategies to identify individuals that have the probability of being carriers of the desired genetic material for breeding, in order to generate a population that will serve as experimental material for further phenotyping, prospection and gene identification work for meat tenderness in the Polled Nellore cattle breed.

\section{MATERIALS AND METHODS}

The construction of this database was possible due to two slaughters, conducted in 2004 and 2008, of a Polled Nellore population with known genealogy and evaluated for meat tenderness.

These slaughters are derived from a study conducted by Marca OB Ranch and the Brazilian Agricultural Research Corporation - Embrapa for characterization and genetic selection for meat tenderness in Polled Nellore. In this study, 22 sires were selected representing the main Nellore bloodlines to be mated with 552 Polled Nellore cows. The progenies of these matings were raised on pasture, finished in feedlot for three months and slaughtered with ages ranging from 24 to 26 months old.

In the first study, 234 animals, offspring of pure breed Polled Nellore sires and commercial Polled Nellore dams, born between October 2002 and January 2003 were slaughtered in November 2004, at an average age of 24 months. In the second study, 181 animals, offspring of pure breed Polled Nellore sires and dams, born between February and April of 2006 were slaughtered in August 2008 at an average age of 26 months. Due to these experimental slaughters, complete pedigree and phenotypic evaluations for carcass and meat tenderness data of 415 progenies of pure breed Polled Nellore sires and dams were produced, forming a relationship matrix containing 956 animals.

The analyzed traits were: initial live weight (ILW); final live weight (FLW); average daily gain (ADG); longissimus muscle area (LMA); rump fat thickness (RF); backfat thickness at the 12th-13th rib (BF); and Warner-Bratzler shear force (WBSF), determined using the Longissimus dorsi muscle after ageing for seven days at $4{ }^{\circ} \mathrm{C}$ (WHEELER et al., 2005).

The statistical analyses were conducted using SAS $^{\circledR}$ (Statistical Analysis System, 2004), through UNIVARIATE, MEANS, GLM and CORR procedures, the latter being used to obtain the Pearson's correlation, and the difference between statistical measures were tested by Tukey's test $(\mathrm{p}<0.05)$. The FACTOR and CANCOR procedures were used for multivariate analyses. 
The animals' pedigree information was organized so that similar groups were formed by using CLUSTER procedure. Clusters were defined using Ward's method (HAIR et al., 2005).

The variance components needed to obtain the genetic parameters were estimated by the Gibbs Sampling method, as described by Van Tassell and Van Vleck (1996), using the MTGSAM (Multiple Trait using Gibbs Sampler under Animal Model) program. The basic linear model for single trait and bivariate analyses was:

$$
y=X \beta=Z u+e
$$

where $y=$ vector of the dependent variable, $\beta=$ vector of fixed effects, $X=$ incidence matrix that associates $\beta$ with $y, Z=$ incidence matrix that associates the vector $u$ to $y, u=$ vector of additive genetic effects, and $e=$ vector of residual effects. The linear model included the additive genetic and residual random effects, the fixed effects of the animal sex and contemporary group (formed by year of slaughter and slaughter date) and the systematic effect of age as covariate.

For the prior values of additive and residual (co)variances the uninformative or "flat" (reflecting no prior knowledge of the parameter) distribution was used. In the implementation of the Gibbs Sampling a chain of 1,500,000 cycles was used, the first 500,000 cycles were discarded (burn in period) and the samples taken every 1,000 cycles, totaling 1,000 Gibbs samples. For convergence evaluation the GIBANAL software (VAN KAAM, 1997) was used.

To identify animals with higher and lower genetic potential for meat tenderness, the data analyses were based on the relationship structure among animals connected to individuals with genetic and phenotypic information regarding meat tenderness.

The analytical procedures, implemented in SAS $^{\circledR}$, were conducted using the principle of identical genes probability by descent to ancestral "founders", that were more likely to be carriers of genes favorable to express the trait of interest, as proposed by Lacy (1989). The model can be described as follows:

$$
f_{g}=1 / \sum\left(\frac{p_{i}^{2}}{r_{i}}\right)
$$

where $r_{i}$ is the expected portion of the founder $i$ alleles that was retained within the descending population, and $p_{i}$ is the portion of the founder $i$ genes in the descending population.

\section{RESULTS AND DISCUSSION}

The ILW and FLW showed high standard deviations, possibly because the animals were selected by their lineage and not for their weight. The same can be observed when evaluating the carcass data, which presented high coefficients of variation $(46.38 \%$ for BF and $32.88 \%$ for RF), and illustrates the heterogeneity of these group of animals studied, in other words, that occurred because these animals were not pre-selected based on their phenotype, but based on their genealogy (Table 1).

The WBSF trait also showed a high coefficient of variation $(29.51 \%)$, indicating heterogeneity of the data set with values ranging from 1.53 to $8.84 \mathrm{~kg}$. This high variation of WBSF within a population or contemporary group has been reported previously (LAGE et al., 2012). Although there are studies indicating genetic influences on meat tenderness (SAINZ et al., 2005), this trait is highly influenced by environmental factors, ante mortem or post mortem (PARDI et al., 2005), which results in a high heterogeneity of WBSF values even within one population.

The means obtained for growth traits (ILW, FLW and ADG) in this population were $372 \mathrm{~kg}, 428 \mathrm{~kg}$ and $1.11 \mathrm{~kg} \mathrm{day}^{-1}$, respectively. It is noteworthy that, when analyzing the data of ILW and FLW, there was a wide variation between the minimum and maximum values for these features. This occurred because those animals were selected in order to form an experimental population, thus, they were selected primarily for their lineage and not according to a margin of predetermined weight. This heterogeneity of weights as a result of a selection based on the animals' lineage was also reported by Sainz et al. (2005).

The characteristics related to carcass quality measured in vivo by ultrasound, such as LMA, BF and $\mathrm{RF}$, showed mean values of $67.49 \mathrm{~cm}^{2}, 5.91 \mathrm{~mm}$ and $8.34 \mathrm{~mm}$, respectively. Previous studies (COSTA et al., 2005; SILVA et al., 2004; YOKOO et al., 2009) indicate that even when considering research using animals of the same breed, the values of growth and carcass traits differ considerably from one study to another. This is probably due to variations in types of management and feed regimes, as well as the ages at which the measures were obtained.

The mean WBSF value found $(3.97 \mathrm{~kg}$ ) was similar to that reported by Lage et al. (2012), who obtained 3.39 $\mathrm{kg}$ for Nellore animals. Higher values were reported by Razook et al. (2001), who, analyzing different herds of Zebu and Caracu animals, obtained values of WBSF in the Longissimus dorsi of 5.4, 4.4, 4.6 and $4.4 \mathrm{~kg}$ for Gir, 
Table 1 - Descriptive statistics for growth (ILW, FLW and ADG), carcass (LMA, BF and RF) and tenderness (WBSF) traits of Polled Nellore cattle breed

\begin{tabular}{lccccccc}
\hline \multirow{3}{*}{ Growth } & Traits & N & Mean & SD & CV (\%) & Minimum & Maximum \\
& ILW (kg) & 284 & 372.08 & 49.48 & 13.30 & 250 & 510 \\
& FLW (kg) & 364 & 427.66 & 59.22 & 13.85 & 290.23 & 604 \\
\multirow{5}{*}{ Carcass } & ADG (kg/day) & 288 & 1.11 & 0.22 & 19.71 & 0.289 & 1.918 \\
& LMA (cm $\left.{ }^{2}\right)$ & 310 & 67.49 & 8.26 & 12.24 & 46.04 & 95.93 \\
Tenderness & BF (mm) & 344 & 5.91 & 2.74 & 46.38 & 0.18 & 18.10 \\
\hline N & RF (mm) & 228 & 8.34 & 2.74 & 32.88 & 3.14 & 18.37 \\
\hline
\end{tabular}

$\mathrm{N}$ : $\mathrm{n}^{\circ}$ of animals, CV: coefficient of variation, SD: Standard Deviation, IWL: initial live weight, FLW: final live weight, ADG: average daily gain, LMA: longissimus muscle area, BF: backfat thickness at the 12th-13th rib, RF: rump fat thickness, WBSF: Warner-Bratzler shear force of the Longissimus dorsi

Guzerat, Nellore and Caracu breeds, respectively. Previous work shows that WBSF values tend to decrease with the addition of Bos taurus genes through crossbreeding (LAGE et al., 2012). The WBSF values also decrease as beef ageing time increases (BIANCHINI et al., 2007) and when animals are slaughtered at younger ages (BIANCHINI et al., 2007: RUBIANO et al., 2009).

With the increased proportion of Zebu genes a decrease in calpain activity occurs which, according Pardi et al. (2005), is the most important enzyme in meat ageing, for degrading myofibrillar proteins and thus achieving optimal tenderness. The reduced rate of ageing in beef from Zebu animals is due to a higher activity of calpastatin, an endogenous protein that inhibits calpain activity (O'CONNOR, TATUM and WULF, 1997). When the calpains are inhibited, the rate of fragmentation of muscle fibers during the post mortem period is decreased.

Significant differences in ILW, FLW and ADG were observed between animals with high and low WBSF. Animals with lower WBSF proved to be heavier and with greater average daily gain than the animals with higher WBSF. There was no significant difference between the two groups of WBSF phenotypes in the carcass traits (LMA, BF and RF).

There were significant differences between males and females for growth (ILW, FLW and ADG), carcass (LMA, BF and RF) and tenderness (WBSF) traits. The males evaluated in both slaughters showed higher ILW, FLW, ADG, LMA and WBSF than the females, but the females showed greater BF larger than the males. This was probably because females tend to reach maturity earlier compared to males, therefore, they enter early in the fattening stage and have lower carcass weight and greater fat thickness compared to males (RODRIGUES et al., 2010) (Table 2).

No significant phenotypic correlations ( $\mathrm{p}>0.05$ ) were observed between growth traits (ILW, FLW and ADG) or carcass traits (LMA, BF and RF) and WBSF (Table 3). To better understand the structure of the phenotypic correlations among traits, an analysis of factors was performed using multivariate techniques. The factorial analysis describes the dependence structure of a set of variables by creating factors that measure common aspects (JOHNSON; WHICHERN, 1998), in other words,

Table 2 - Comparison of growth, carcass and tenderness traits between males and females and between animals with high and low WBSF

\begin{tabular}{cccccccc}
\hline & ILW & FLW & ADG & LMA & BF & RF & WBSF \\
\hline High WBSF & 304 B & $426 \mathrm{~B}$ & $1.11 \mathrm{~B}$ & $66.81 \mathrm{~A}$ & $5.92 \mathrm{~A}$ & $8.35 \mathrm{~A}$ & $4.63 \mathrm{~A}$ \\
Low WBSF & 320 A & $442 \mathrm{~A}$ & $1.17 \mathrm{~A}$ & $68.02 \mathrm{~A}$ & $5.99 \mathrm{~A}$ & $8.36 \mathrm{~A}$ & $2.93 \mathrm{~B}$ \\
Female & $252 \mathrm{~B}$ & $396 \mathrm{~B}$ & $1.06 \mathrm{~B}$ & $65.71 \mathrm{~B}$ & $7.03 \mathrm{~A}$ & $9.58 \mathrm{~A}$ & $4.09 \mathrm{~A}$ \\
Male & $344 \mathrm{~A}$ & $470 \mathrm{~A}$ & $1.17 \mathrm{~A}$ & $69.67 \mathrm{~A}$ & $4.72 \mathrm{~B}$ & $7.19 \mathrm{~B}$ & $3.85 \mathrm{~B}$ \\
\hline
\end{tabular}

AB: Means followed by uppercase distinct superscripts indicates significantly statistical difference (p < 0.05) by Tukey's test; IWL: initial live weight, FLW: final live weight, ADG: average daily gain, LMA: longissimus muscle area, BF: backfat thickness at the 12th-13th rib, RF: rump fat thickness, WBSF: Warner-Bratzler shear force of the Longissimus dorsi 
Table 3 - Phenotypic correlation estimates between growth (ILW, FLW, ADG), carcass (LMA, BF, RF) and tenderness (WBSF) traits of Polled Nellore cattle

\begin{tabular}{|c|c|c|c|c|c|c|}
\hline & FLW & $\mathrm{ADG}$ & LMA & $\mathrm{BF}$ & $\mathrm{RF}$ & WBSF \\
\hline \multirow[t]{2}{*}{ ILW } & 0.91 & 0.50 & 0.34 & -0.11 & 0.08 & -0.02 \\
\hline & $* * *$ & $* * *$ & $* * *$ & ns & ns & ns \\
\hline \multirow[t]{2}{*}{ FLW } & & 0.69 & 0.49 & -0.03 & 0.14 & -0.08 \\
\hline & & $* * *$ & $* * *$ & ns & $* *$ & ns \\
\hline \multirow[t]{2}{*}{$\mathrm{ADG}$} & & & 0.36 & 0.08 & 0.22 & -0.06 \\
\hline & & & $* * *$ & 0.2064 & $* *$ & ns \\
\hline \multirow[t]{2}{*}{ LMA } & & & & 0.13 & 0.38 & -0.10 \\
\hline & & & & 0.022 & $* * *$ & ns \\
\hline \multirow[t]{2}{*}{$\mathrm{BF}$} & & & & & 0.59 & -0.03 \\
\hline & & & & & $* * *$ & ns \\
\hline $\mathrm{RF}$ & & & & & & -0.03 \\
\hline
\end{tabular}

Significance: $*(\mathrm{p}<0.05)$; **(p<0.01); ***(p<0.001); ns: not significant; IWL: initial live weight, FLW: final live weight, ADG: average daily gain, LMA: longissimus muscle area, BF: backfat thickness at the 12th-13th rib, RF: rump fat thickness, WBSF: Warner-Bratzler shear force of the Longissimus dorsi

the factor analysis will compare the groups in terms of similarity and dissimilarity and correlation.

The results of the factor analysis of the features are shown in Table 4, indicating that a minimum of three factors were needed to explain more than $80 \%$ of the total variance.

Table 4 - Common factors analysis, percentage of explained variance by each factor and cumulative variance

\begin{tabular}{lccc}
\hline Eigenvectors & Autovalue & $\begin{array}{c}\text { Explained } \\
\text { variance } \\
(\%)\end{array}$ & $\begin{array}{c}\text { Cumulative } \\
\text { variance } \\
(\%)\end{array}$ \\
\hline Factor 1 & 3.445 & 0.43 & 0.43 \\
Factor 2 & 1.973 & 0.25 & 0.68 \\
Factor 3 & 1.003 & 0.13 & 0.80 \\
\hline
\end{tabular}

Factors 1, 2 and 4 were responsible for $43 \%$, $25 \%$ and $14 \%$ of the variances presented by all the traits, respectively. To better visualize the interrelationships explained by the sources of variation presented by the factor vectors, the three eigenvectors are graphically represented in Figure 1. Factor 1 was responsible for explaining mainly the variability of ILW and FLW traits. Factor 2 explained the variability of ILW, FLW, ADG, BF, RF and LMA and factor 3 represented the WBSF trait.
Figure 1 shows the cause of more similar variations, by grouping together the traits that most explain the variance in the data set. The sources of variation of each group make them more similar and are used in cluster formation, in other words, the most similar traits are more related to each other in a positive linear relationship.

Figure 1 - Graphical relationship between the eigenvectors 1,2 and 3

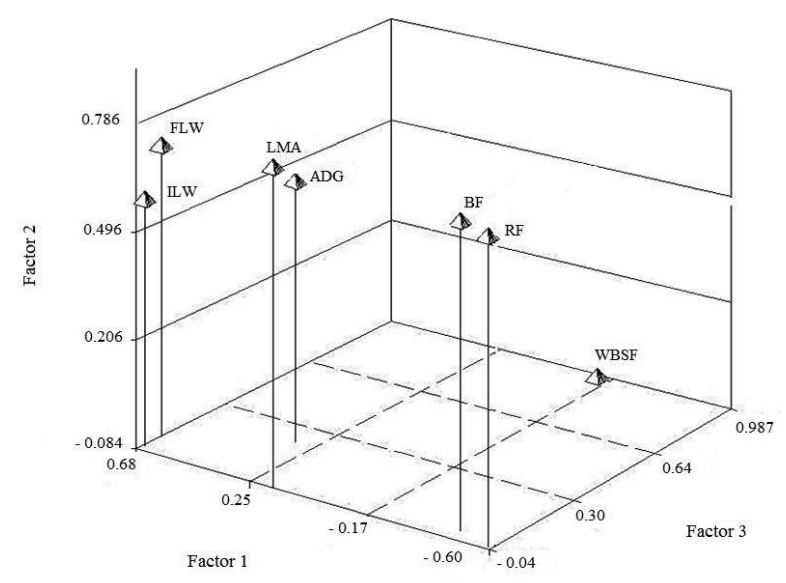

IWL: initial live weight, FLW: final live weight, ADG: average daily gain, LMA: longissimus muscle area, BF: backfat thickness at the 12th13th rib, RF: rump fat thickness, WBSF: Warner-Bratzler shear force of the Longissimus dorsi 
Distinct groups of traits were observed within the data set, i.e., weight (ILW and FLW), lean growth (ADG and LMA) and fatness (BF and RF) traits. The WBSF trait did not correlate with any of the others, as can be seen in Figure 1.

In order to better demonstrate the relationships among traits, another multivariate analysis technique, canonical correlation analysis, was used. This technique generates new values (canonical eigenvalues) that best explain the correlations between all the traits and thus assists in the analysis of phenotypic correlations between the variables. The circles in the canonical correlation plot (Figure 2) show the major groupings that resulted.

Figure 2 - Graphical representation of the canonical correlation between growth (ILW, FLW, ADG), carcass (LMA, BF, RF) and tenderness (WBSF) traits

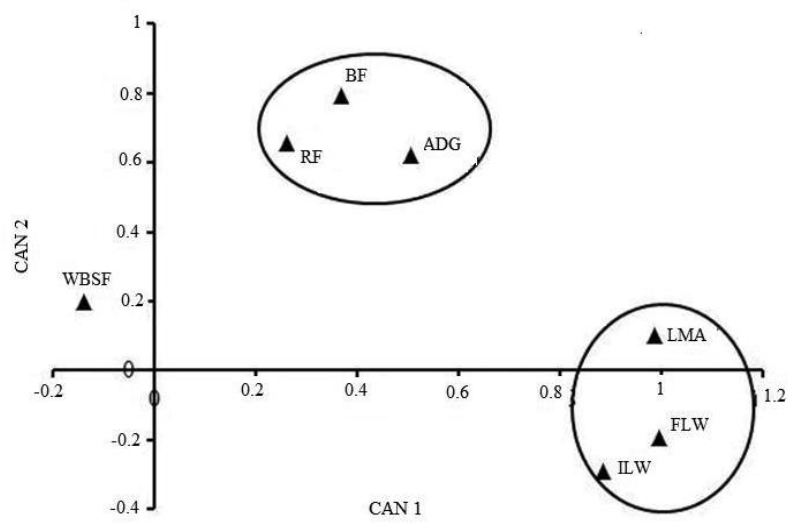

IWL: initial live weight, FLW: final live weight, ADG: average daily gain, LMA: longissimus muscle area, BF: backfat thickness at the 12th-13th rib, RF: rump fat thickness, WBSF: Warner-Bratzler shear force of the Longissimus dorsi

The canonical correlation analysis shows that the traits form two separate groups. The first includes ADG and fat thickness (BF and RF). The second group includes weight (ILW and FLW) and muscularity (LMA) traits. However, the WBSF trait did not group with any of the other studied features, confirming the results obtained in the previous analyses.

The variance components estimation for WBSF showed that this trait does not have significant values of additive genetic variance. This can be observed by the low additive genetic variance estimate $(0.148)$ and the high residual (1.222) and phenotypic (1.370) variances presented. These values of direct additive genetic and phenotypic variances generated a heritability estimate of $0.11 \pm 0.022$, suggesting that only $11 \%$ of the WBSF genes have direct additive genetic effects, while $89 \%$ of the effects that control this feature are present in the residue, this being composed of epistatic, dominance, genotype-environment interactions and environmental effects (Table 5).

Table 5 - Variance components and genetic parameters analysis of WBSF (Warner-Bratzler shear force) of the Longissimus dorsi of Polled Nellore cattle obtained from univariate analysis in animal model

\begin{tabular}{ccccc}
\hline Traits & $\sigma_{a}^{2}$ & $\sigma_{e}^{2}$ & $\sigma_{p}^{2}$ & $\mathrm{~h}^{2}$ \\
\hline WBSF & 0.148 & 1.222 & 1.370 & $0.11( \pm 0.022)$ \\
\hline WBSF: Warner-Bratzler shear force of the Longissimus dorsi beef; & sence \\
$\sigma_{a}^{2}$ : additive genetic variance; $\sigma_{e}^{2}$ : residual variance; $\sigma_{p}^{2}$ : phenotypic \\
variance; $\mathrm{h}^{2}$ : heritability
\end{tabular}

The heritability value of WBSF in this study was similar to that found by Elzo et al. (1998), who found heritability of 0.17 for WBSF in Brahman animals and crosses. Smith et al. (2007) reported higher heritability values for WBSF in Brahman cattle, obtaining estimates around 0.29. Clearly the heritability for meat tenderness can present substantial variation even among animals of the same breed. Other reports in the literature also demonstrate heritabilities ranging from low to high magnitude, whether within or between breeds (BOUKHA et al., 2011; JOHNSTON et al., 2003; MINICK et al., 2004). However, there are few studies that are directly comparable with the results found in this study, because most of the research with gene prospection of meat quality features refers to Bos taurus breeds and their crossbreds with Zebu cattle (ELZO et al., 1998; JOHNSTON et al., 2003).

The genetic correlation estimates (Table 6) between the growth traits (ILW, FLW and ADG) and WBSF were negative and of low magnitudes $(-0.15,-0.18$ and -0.13 , respectively), indicating that the selection for WBSF will not influence directly the selection for weight and vice versa. A negative and low magnitude (-0.12) correlation also occurred between WBSF and fat thickness measured on the rump (RF), indicating that the joint selection for these traits will not influence their phenotypic expression.

For the other carcass traits, BF and LMA, despite also being of a low magnitude, the genetic correlations with WBSF were positive ( 0.10 and 0.18 , respectively). Although the positive genetic correlation estimate between WBSF and LMA can be explained by the increase in muscle size with age and consequently decreased meat 
tenderness, these results must be interpreted with caution due to the very large $95 \%$ confidence regions.

Genetic correlations between WBSF and carcass traits (BF and LMA) were also observed by Koch, Cundiff and Gregory (1982) who obtained a value of -0.01 for the genetic correlation between WBSF and $\mathrm{BF}$, and a value of -0.02 between WBSF and LMA. Although these genetic correlations were negative, opposite to those obtained in this study, they were also of a very low magnitude, indicating that the selection for WBSF should not influence the selection for the mentioned carcass traits.

The heritability estimates (Table 7) obtained for the traits related to carcass quality by bivariate Bayesian analysis, measured in vivo by ultrasound, were 0.29 , 0.37 and 0.74 for LMA, BF and RF, respectively. These values can be considered from moderate (LMA and BF) to high (RF) magnitude, but the heritability estimates obtained in this study for the growth traits as ILW, FLW and ADG were of high magnitude, with values of
$0.88,0.79$ and 0.61 , respectively. Literature values of heritabilities for weight, especially for yearling weight and weight gain, vary widely. Bergmann (2003) reported variation from 0.08 to 0.83 for direct heritability for yearling weight in studies with various breeds of beef cattle, and the author further stated that due to the great use of the trait as a selection criterion, several authors have been concerned with obtaining more accurate estimates of the genetic parameters.

The magnitudes of heritability presented by the studied traits show that these can be passed from one generation to the next, in other words, there may be genetic progress in applying the selection for the same. Thus, in a breeding program it will be possible to select and improve both carcass and / or growth traits as well as the tenderness trait, not through a correlated response, but rather due to the high heritabilities of the traits.

There was also a wide amplitude of values of the credibility region at $95 \%$ (CR 95\%) in the bivariate

Table 6 - Descriptive statistics of the (co) variance components and heritability estimates and genetic correlations between WBSF and ILW, FLW, ADG, BF, RF and LMA traits, in Polled Nelore cattle, obtained from bivariate analyses in animal model

\begin{tabular}{|c|c|c|c|c|c|c|}
\hline \multirow{2}{*}{ Traits } & & \multicolumn{3}{|c|}{ (co) variance components } & \multicolumn{2}{|c|}{ Genetic parameters } \\
\hline & & $\sigma_{a 1}^{2}$ & $\sigma_{a 12}^{2}$ & $\sigma_{e l}^{2}$ & $h_{1}^{2}$ & $r_{g 12}$ \\
\hline \multirow{3}{*}{$\mathrm{WBSF}^{1} \mathrm{x} \mathrm{ILW}^{2}$} & Mean & 0.128 & -1.315 & 1.238 & 0.09 & -0.15 \\
\hline & $\mathrm{SD}$ & 0.122 & 4.396 & 0.136 & 0.09 & 0.55 \\
\hline & $\mathrm{CR}(95 \%)$ & 0.007 to 0.434 & -10.308 to 6.920 & 0.931 to 1.493 & 0.01 to 0.32 & -0.98 to 0.99 \\
\hline \multirow{3}{*}{$\mathrm{WBSF}^{1} \times \mathrm{FLW}^{2}$} & Mean & 0.161 & -2.612 & 1.218 & 0.11 & -0.18 \\
\hline & $\mathrm{SD}$ & 0.176 & 8.209 & 0.162 & 0.11 & 0.56 \\
\hline & $\mathrm{CR}(95 \%)$ & 0.009 to 0.681 & -21.113 to 12.330 & 0.823 to 1.476 & 0.01 to 0.45 & -0.99 to 0.88 \\
\hline \multirow{3}{*}{$\mathrm{WBSF}^{1} \times \mathrm{ADG}^{2}$} & Mean & 0.189 & -0.008 & 1.196 & 0.13 & -0.13 \\
\hline & $\mathrm{SD}$ & 0.176 & 8.209 & 0.168 & 0.12 & 0.62 \\
\hline & $\mathrm{CR}(95 \%)$ & 0.010 to 0.640 & -0.110 to 0.09 & 0.830 to 1.480 & 0.01 to 0.42 & -0.99 to 0.97 \\
\hline \multirow{3}{*}{$\mathrm{WBSF}^{1} \times \mathrm{BF}^{2}$} & Mean & 0.190 & 0.073 & 1.211 & 0.12 & 0.10 \\
\hline & $\mathrm{SD}$ & 0.176 & 0.046 & 0.170 & 0.12 & 0.60 \\
\hline & $\mathrm{CR}(95 \%)$ & 0.009 to 0.621 & -0.794 to 0.974 & 0.843 to 1.499 & 0.01 to 0.43 & -0.96 to 0.99 \\
\hline \multirow{3}{*}{$\mathrm{WBSF}^{1} \times \mathrm{RF}^{2}$} & Mean & 0.148 & -0.114 & 1.229 & 0.11 & -0.12 \\
\hline & $\mathrm{SD}$ & 0.143 & 0.474 & 0.145 & 0.10 & 0.60 \\
\hline & $\mathrm{CR}(95 \%)$ & 0.004 to 0.531 & -1.079 to 0.807 & 0.894 to 1.482 & 0.01 to 0.37 & -0.99 to 0.97 \\
\hline \multirow[t]{3}{*}{$\mathrm{WBSF}^{1} \times \mathrm{LMA}^{2}$} & Mean & 0.199 & 0.285 & 1.184 & 0.14 & 0.18 \\
\hline & $\mathrm{SD}$ & 0.217 & 1.345 & 0.187 & 0.14 & 0.63 \\
\hline & $\mathrm{CR}(95 \%)$ & 0.008 to 0.895 & -3.055 to 3.327 & 0.637 to 1.479 & 0.01 to 0.54 & -0.97 to 0.99 \\
\hline
\end{tabular}

1: Warner-Bratzler shear force of the Longissimus dorsi (WBSF); ${ }^{2}$ : initial live weight (ILW), final live weight (FLW), average daily gain (ADG), longissimus muscle area (LMA), backfat thickness at the 12 th-13th rib (BF), rump fat thickness (RF); $\sigma^{2}{ }_{a l}$ : additive genetic variance of $1 ; \sigma_{a l 2}^{2}$ : additive genetic covariance between 1 and $2 ; \sigma^{2}{ }_{e l}$ : residual variance of $1 ; h_{l}^{2}:$ heritability of $1 ; r_{g / 2}:$ genetic correlation between 1 and 2; SD: standard deviation; CR: credibility region at $95 \%$ 
Table 7 - Descriptive statistics of the (co) variance components and heritability estimative and genetic correlation between ILW, FLW, ADG, BF, RF and LMA traits and the WBSF trait, in Polled Nelore cattle, obtained from bivariate analyses in animal model

\begin{tabular}{|c|c|c|c|c|c|c|}
\hline \multirow{2}{*}{ Traits } & & \multicolumn{3}{|c|}{ (co) variance components } & \multicolumn{2}{|c|}{ Genetic parameters } \\
\hline & & $\sigma_{a l}^{2}$ & $\sigma_{a 12}^{2}$ & $\sigma_{e l}^{2}$ & $h_{1}^{2}$ & $r_{g / 2}$ \\
\hline \multirow{3}{*}{$\mathrm{WBSF}^{1} \mathrm{x} \mathrm{ILW}^{2}$} & Mean & 639.992 & -1.315 & 83.971 & 0.88 & -0.15 \\
\hline & SD & 138.375 & 4.396 & 100.803 & 0.15 & 0.55 \\
\hline & $\mathrm{CR}(95 \%)$ & 289.090 to 845.975 & -10.308 to 6.920 & 0.85 to 374.995 & 0.44 to 1.00 & -0.98 to 0.99 \\
\hline \multirow{3}{*}{$\mathrm{WBSF}^{1} \times \mathrm{FLW}^{2}$} & Mean & 1430.174 & -2.612 & 363.553 & 0.79 & -0.18 \\
\hline & SD & 420.642 & 8.209 & 317.914 & 0.19 & 0.56 \\
\hline & $\mathrm{CR}(95 \%)$ & 544.525 to 2065.225 & -21.113 to 12.330 & 0.730 to 1047.675 & 0.34 to 1.00 & -0.99 to 0.88 \\
\hline \multirow{3}{*}{$\mathrm{WBSF}^{1} \times \mathrm{ADG}^{2}$} & Mean & 0.027 & -0.008 & 0.016 & 0.61 & -0.13 \\
\hline & $\mathrm{SD}$ & 0.015 & 8.209 & 0.012 & 0.30 & 0.62 \\
\hline & $\mathrm{CR}(95 \%)$ & 0.000 to 0.050 & -0.110 to 0.09 & 0.000 to 0.040 & 0.06 to 1.00 & -0.99 to 0.97 \\
\hline \multirow{3}{*}{$\mathrm{WBSF}^{1} \times \mathrm{BF}^{2}$} & Mean & 2.492 & 0.073 & 3.899 & 0.37 & 0.10 \\
\hline & SD & 1.909 & 0.046 & 1.524 & 0.26 & 0.60 \\
\hline & $\mathrm{CR}(95 \%)$ & 0.240 to 7.240 & -0.794 to 0.974 & 0.235 to 6.115 & 0.04 to 0.97 & -0.96 to 0.99 \\
\hline \multirow{3}{*}{$\mathrm{WBSF}^{1} \times \mathrm{RF}^{2}$} & Mean & 4.539 & -0.114 & 1.479 & 0.74 & -0.12 \\
\hline & SD & 1.565 & 0.474 & 1.178 & 0.21 & 0.60 \\
\hline & $\mathrm{CR}(95 \%)$ & 1.425 to 7.105 & -1.079 to 0.807 & 0.030 to 4.040 & 0.26 to 1.00 & -0.99 to 0.97 \\
\hline \multirow{3}{*}{$\mathrm{WBSF}^{1} \mathrm{x} \mathrm{LMA}^{2}$} & Mean & 17.234 & 0.285 & 38.805 & 0.29 & 0.18 \\
\hline & SD & 16.234 & 1.345 & 13.171 & 0.25 & 0.63 \\
\hline & $\mathrm{CR}(95 \%)$ & 0.525 to 59.345 & -3.055 to 3.327 & 6.12 to 56.43 & 0.01 to 0.90 & -0.97 to 0.99 \\
\hline
\end{tabular}

1: Warner-Bratzler shear force of the Longissimus dorsi (WBSF); ${ }^{2}$ : initial live weight (ILW), final live weight (FLW), average daily gain (ADG), longissimus muscle area (LMA), backfat thickness at the 12 th-13th rib (BF), rump fat thickness (RF); $\sigma^{2}{ }_{a l}:$ additive genetic variance of $2 ; \sigma^{2}{ }_{a 12}$ : additive genetic covariance between 1 and $2 ; \sigma_{e l}^{2}$ : residual variance of $2 ; h_{1}^{2}$ : heritability of $2 ; r_{g 12}$ : genetic correlation between 1 and 2 ; SD: standard deviation; CR: credibility region at $95 \%$

analyses presented here (Tables 6 and 7), such as the correlation between WBSF and the initial live weight (ILW). This credibility region at 95\% (95\% CR) ranged from -0.98 to 0.99 , indicating that the analyzed parameter can assume any value within that range.

This high amplitude of the credibility region at 95\% occurred with all analyzed parameters and may indicate that the collected data was insufficient to generate a more consistent analysis and further studies should be conducted to obtain a greater volume of information on the meat tenderness trait.

In general, when considering only the Zebu breeds, especially Nellore, studies addressing tenderness as an object of selection are rather scarce. However, experiments to evaluate this trait are of high cost and long duration, which further complicates large scale collection of tenderness data.

Using the animals' genealogy information, it was possible to identify the Nellore breed founder animals, as described by Magnabosco, Cordeiro and Trovo (1997), that had greater numbers of descendants in this population presenting high or low WBSF. This founder population with descendants that segregate for low WBSF are represented by the letters $\mathrm{D}, \mathrm{E}$ and $\mathrm{F}$, while the founders with descendants that segregate for high WBSF are represented by the letters A, B and C (Figure 3).

Although the founders of the studied population were separated into two groups considering the WBSF phenotype, it was observed that some bulls, descended from the same founder, had progeny that segregated for both tenderness phenotypes, in other words, these bulls had progeny who had low WBSF and also had progeny who had high WBSF. This phenotypic behavior can be explained by the low heritability for the meat tenderness trait in this study and several others reported in the literature (BOUKHA et al., 2011; MINICK et al., 2004).

The strategy of using pedigree information, based on the principle of probability of identical genes by descent, allowed the identification of individuals 
Figure 3 - Distances between founders' dendrogram according to the Warner-Bratzler shear force of the Longissimus dorsi of their respective progenies

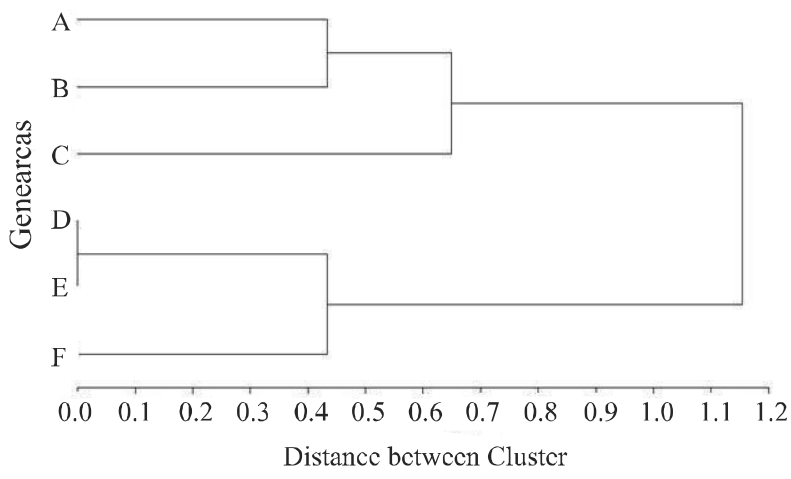

who were more likely to be carriers of tenderness genes, considering that the analyses using Gaussian models in animal models and Bayesian perspective did not allow the prediction of breeding values for WBSF.

\section{CONCLUSIONS}

1. The estimates of (co) variance components and genetic parameters for meat tenderness indicated that most of the genes responsible for the meat tenderness trait (WBSF) have no direct additive genetic effect. The selection for meat tenderness in Polled Nellore will not affect the deposition of subcutaneous fat in the carcass nor the animals' muscularity and vice versa. Furthermore, the results of this study also demonstrated no correlated response between tenderness and growth traits, such as weight and weight gain, indicating that joint selection for those traits will not influence phenotypic expression of tenderness;

2. Using pedigree information and according to the principle of probability of identical genes by descent, individuals who were more likely to be carriers of favorable genes for tenderness were identified. Further work will include creation of a segregating population that will serve as experimental material for future gene prospecting and identification research.

\section{ACKNOWLEDGEMENTS}

To Guaporé Pecuária S/A, owner of the OB brand, for providing the data of the OBChoice Program and for always supporting research and education programs, and also to $\mathrm{CNPq}$, Embrapa and Capes for the funding.

\section{REFERENCES}

BERGMANN, J. A. G. Objetivos e critérios de seleção. In: WORKSHOP SELEÇÃO EM BOVINOS DE CORTE, 4., 2003, Ribeirão Preto. Anais... Ribeirão Preto: ANCP, p.1-8, 2003. [Cd-rom].

BIANCHINI, W. et al. Efeito do grupo genético sobre as características de carcaça e maciez da carne fresca e maturada de bovinos superprecoces. Revista Brasileira de Zootecnia, v. 36, n. 6, p. 2109-2117, 2007.

BOLEMAN, S. J. et al. Consumer evaluation of beef of known categories of tenderness. Journal of Animal Science, Champaign, v. 75, n. 6, p. 1521-1524, 1997.

BOUKHA, A. et al. Genetic parameters of carcass and meat quality traits of double muscled Piemontese cattle.Meat Science, v. 89 , p. $84-90,2011$

BOUQUET, A. et al. Genetic parameters for growth, muscularity, feed efficiency and carcass traits of young beef bulls. Livestock Science, v. 129, p. 38-48, 2010.

COSTA, M. A. L. et al. Desempenho, digestibilidade e características de carcaça de novilhos zebuínos alimentados com dietas contendo diferentes níveis de concentrado. Revista Brasileira de Zootecnia, v. 34, n. 1, p. 268-279, 2005.

ELZO, M. A. et al. Genetic variation and prediction of additive and nonadditive genetic effects for six carcass traits in an Angus-Brahman multibreed herd. Journal of Animal Science, v. 76, n. 7 , p. $1810-1823,1998$.

FERRAZ, J. B. S.; ELER, J. P. Parceria público x privada no desenvolvimento de pesquisa em melhoramento genético animal. Revista Brasileira de Zootecnia, v. 39, suppl. spe, p. 216-222, 2010.

HAIR, J. F. et al. Análise multivariada de dados. 5. Ed. Porto Alegre: Bookman, 2005. 593p.

HERD, R.M.; ARCHER, J.A.; ARTHUR, P.F. Steers growth and feed efficiency on pasture are favourably associated with genetic variation in sire net feed intake. Animal Production in Australia, v. 25, p. 93-96, 2004.

HOQUE, M. A. et al. Genetic parameters for measures of residual feed intake and growth traits in seven generations of Duroc pigs. Livestock Science. v. 121, p. 45-49, 2009.

IBGE - Instituto Brasileiro De Geografia e Estatística. Produção da pecuária municipal - PPM 2010, 2011. Disponível em: <http://www.ibge.gov.br>. Acesso em: 20 jan. 2012.

JOHNSON, R. A; WICHERN, D. W. Applied multivariate statistical analysis.4ed. New Jersey: Prentice-Hall, 1998.

JOHNSTON, D. J. et al. Genetic and phenotypic characterization of animal, carcass, and meat quality traits 
from temperate and tropically adapted beef breeds. 3. Meat quality traits. Australian Journal of Agricultural Research, v. 54, p. 135-147, 2003.

KOCH, R. M.; CUNDIFF, L. V.; GREGORY, K. E. Heritabilities and genetic, environmental and phenotypic correlations of carcass traits in a population of diverse biological types and their implications in selection programs. Journal of Animal Science, v. 55, n. 6, p. 1319-1329, 1982.

LACY, R. C. Analysis of founder representation in pedigrees: Founder equivalents and founder genome equivalents. Zoo Biology, v. 8, p. 111-123, 1989.

LAGE, J. F. et al. Influence of genetic type and level of concentrate in the finishing diet on carcass and meat quality traits in beef heifers. Meat Science, v. 90, p. 770-774, 2012.

LANCASTER, P.A. et al. Phenotypic and genetic relationships of residual feed intake with performance and ultrasound carcass traits in Brangus heifers. Journal of Animal Science, v. 87, n. 12, p. 3887-3896, 2009.

LOPES, F. B. et al. Ajustes de curvas de crescimento em bovinos Nelore da região Norte do Brasil. Revista Brasileira de Saúde e Produção Animal, v. 12, n. 3, p. 607-617, 2011.

LOPES, F. B. et al. Tendência genética para características relacionadas a velocidade de crescimento em bovinos Nelore da região Norte do Brasil. Revista Ciência Agronômica, v. 43, n. 2, p. 362-367, 2012.

MAGNABOSCO, C. U.; CORDEIRO, C. M. T.; TROVO, J. B. Catálogo de linhagens do germoplasma zebuíno: raça Nelore. Brasília: Embrapa - Cenargen, 52p., 1997.

MINICK, J. A. et al. Heritability and correlation estimates of Warner-Bratzler shear force and carcass traits from Angus, Charolais, Hereford, and Simmental-sired cattle. Canadian Journal of Animal Science, v. 84, p. 599-609, 2004.

O'CONNOR, S.F.; TATUM, J.D.; WULF, D.M. Genetics effects on beef tenderness in Bos indicus composite and Bos taurus cattle. Journal of Animal Science, v.75, n.7, p. 18221830, 1997.

PARDI, M. C.et al. Ciência, higiene e tecnologia da carne. 2. Ed. UFG, 2005. 623p.

RAZOOK, A. G. et al.Efeitos de raça e da seleção para peso pós-desmame sobre características de confinamento e de carcaça da $15^{\mathrm{a}}$ progênie dos rebanhos zebu e caracu de sertãozinho. Revista Brasileira de Zootecnia, v. 30, n. 1, p. 115-124, 2001.

ROBINSON, D. L.; ODDY, V. H. Genetics parameters for feed efficiency, fatness, muscle area, and feeding behavior of feedlot finished beef cattle. Livestock Production Science, v. 90, p. 255-270, 2004.
RUBIANO, G. A. G. et al. Desempenho, características de carcaça e qualidade da carne de bovinos superprecoces das raças Canchim, Nelore e seus mestiços. Revista Brasileira de Zootecnia, v. 38, n. 12, p. 2490-2498, 2009.

RODRIGUES, E. et al. Crescimento dos tecidos muscular e adiposo de fêmeas bovinas de diferentes grupos genéticos no modelo biológico superprecoce. Revista Brasileira de Zootecnia, v. 39, n. 3, p. 625-632, 2010.

SAINZ, R. D. et al. Projeto OB-Choice: genética para melhorar a qualidade da carne brasileira. In: CONGRESSO BRASILEIRO DE CIÊNCIAE TECNOLOGIA DE CARNES, 3., 2005, São Pedro. Anais... São Pedro: CTC, p. 265, 2005.

SANTOS, G. C. J. et al. Tendência genética para pesos padronizados aos 205, 365 e 550 dias de idade de bovinos nelore da região Norte do Brasil. Acta Scientiarum. Animal Sciences, v. 34, p. 97-101, 2012.

SAS INSTITUTE INC. SAS onlineDOC ${ }^{\circledR}$ 9.1.3, Cary, NC. 2004.

SILVA, S. L. et al. Estimativa da gordura de cobertura ao abate, por ultra-som, em tourinhos Brangus e Nelore. Revista Brasileira de Zootecnia, v. 33, n. 2, p. 511-517, 2004.

SMITH, T. et al. Genetic parameters for growth and carcass traits of Brahman steers. Journal of Animal Science, v. 85, n. 6, p. 1377-1384, 2007.

SOUZA, J. C. et al. Tendências ambientais e genéticas para características produtivas de bovinos da raça Nelore. Archivos Latino americanos de Producción Animal, v. 16, n. 2, p. 85-90, 2008.

USDA - United States Department of Agricultural. Livestock and Poltry: World Markets and Trade. Disponível em: http://www.usda.gov. Acesso em: 19/12/2013.

VAN KAAM, J. Gibanal - Analyzing program for Markov Chain Monte Carlo sequences. Version 2.4, Department of Animal Breeding, Wageningen-Netherlands, 1997.

VAN TASSELL, C. P.; VAN VLECK, L. D. Multiple-trait Gibbs sampler for animal models: flexible programs for Bayesian and likelihood-based (co)variance component inference. Journal of Animal Science, v. 74, n.11, p. 25862597, 1996.

WHEELER, T. L.; CUNDIFF, L. V.; SHACKELFORD, S. D.; KOOHMARAIE, M. Characterization of biological types of cattle (Cycle VII): Carcass, yield, and longissimus palatability traits. Journal of Animal Science, Champaign, v. 83 , n. 1, p. 196-207, 2005.

YOKOO, M. J. I. et al. Correlações genéticas entre escores visuais e características de carcaça medidas por ultrasom em bovinos de corte. Pesquisa Agropecuária Brasileira, v. 44, n. 02, p. 197-202, 2009. 